\title{
Corporate Tax Saving In Indonesia
}

\author{
PRIANTO BUDI SAPTONO* \\ NENCY, VONNICIA**
}

\begin{abstract}
* Master of Administration Science Lecturer - Tax Management - Institute STIAMI
***Master of Administration Science Students - Tax Management - Institute STIAMI

Email:nency.bc201120035@gmail.com, vonniciakiang@gmail.com
\end{abstract}

DOI: 10.29322/IJSRP.11.05.2021.p11315

http://dx.doi.org/10.29322/IJSRP.11.05.2021.p11315

\begin{abstract}
Based on data from Presidential Decree No. 72 of 2020, around 82,62\% of Indonesia's State Budget (APBN) comes from the domestic tax revenue sector (Data January 2020 to August 2020). Domestic taxes' dominant contributions include income tax, value-added tax, customs and excise, land and building tax, and other taxes.

Since the Covid-19 Pandemic case in Indonesia, the Indonesian Government has continued to issue various kinds of Tax Incentives to ease the burden on the people and ensure business continuity in Indonesia. The enactment of Government Regulation (Perpu) Number 2 of 2020 is an urgency that the Government cannot avoid.

In addition to allowing the state budget deficit to be below 3\%, the Tax Service Office has also begun to increase the issuance of Request of Explanation on Data and/or Information (SP2DK) and Inspection Warrant (SP2) to taxpayers. It is done to test taxpayers' compliance following Article 4 of the Minister of Finance Regulation No. 184 / PMK.03 / 2015.

However, from the perspective of entrepreneurs and Taxpayer at the same time, they have different interests from the Government, namely how to get the maximum profit and pay the minimum tax. Due to the obligation to pay taxes has been regulated in the Law, Tax Avoidance and Tax Evasion cannot be applied by taxpayers if they want a long-term business profit in Indonesia. For this reason, this article further describes the tax planning that corporate taxpayers can implement following the laws in force in Indonesia.
\end{abstract}

Keywords: Corporate Tax Saving, Tax Planning, Indonesia.

\section{PRELIMINARY}

Based on information sources from Kontan.co.id, Organisation for Economic Co-operation and Development (OECD) released a report on July 24, 2019, regarding the development of an increase in the tax ratio (tax ratio) to National Income (GDP) in several countries. The report states sources of revenue for countries in the Asia Pacific region.

"According to the report contained in the sixth edition of Revenue Statistics in Asian and Pasific Economies, Wednedsay (24/7), the sources of tax revenue for nine of the 17 Asian and Pacific countries surveyed as of 2017 were taxes on goods and services (goods and services taxes/GST)."

"Meanwhile, seven other countries received the largest tax revenue from income tax, namely Australia, Korea, Malaysia, New Zealand, Papua New Guinea, Singapore and Tokelau. Particularly in Malaysia and Singapore, the portion of Corporate Income Tax is greater than Personal Income Tax".

Indonesia is one of the countries whose source of state revenue is dominated by domestic tax revenues. To finance State Expenditures, the target of tax revenues in the last few years has continuously been increasing. It can be clarified from the data on Comparison of KPI Achievement from 2017 to 2019 in the Performance Report of the Directorate General of Taxes for 2019, where the tax revenue target in 2017 is Rp 1.283,57 trillion, 2018 is Rp 1.424 trillion, 2019 is Rp 1.577,56 trillion.

In its realization, the Directorate General of Taxes Performance Report for 2019 noted, the achievement of IKU (Main Performance indicator) in 2017 was $89,67 \%$, and in 2018 was 92,23\%, while in 2019, it decreased to 84,44\%.

Along with the entry of the Covid-19 pandemic into Indonesia, the APBN no longer only prepared for State Expenditure related to the development of State facilities and infrastructure but also subscribers to Covid-19 itself. During 2020, several government policies have been issued to deal with Covid-19 and the resulting impact of Covid-19. State spending in the 2020 State Budget also includes several tax incentives borne by the Government. It is done by the Government to ensure the people's welfare and maintain business continuity in Indonesia.

According to information published in Kontan.co.id, on January 6, 2021, the Ministry of Finance (Kemenkeu) recorded a deficit in the state budget (APBN) throughout 2020 of Rp 956,3 trillion. His figure is equivalent to 6,09\% of gross domestic 
product (GDP). However, the 2020 state budget deficit is still below the Government's outlook of 6,34\% as mandated in the Presidential Regulation (Perpres) 72/2020 regarding the 2020 Fiscal Year State Budget posture.

"The APBN is working tremendously so that our APBN maintains this tremendous pressure, which is the design of the consplidation, but still supports the economy so that it really keeps on recorvering." said the MinisterMinister.

Globally, economic recovery is an urgency for all leaders of the country, none other than Indonesia. To realize the Vision of a Forward Indonesia 2045 as the 5 (five) significant powers of the World Economic by 2045, the Indonesian Government continues to encourage investment funding amid the conditions of the world economic slowdown. The Indonesian Government's Regulation is also implemented in Law Np. 11 of 2020 concerning Job Creation / Omnibus Law, passed on November 2, 2020.

Besides the existence of tax incentives for Taxpayers affected by Covid-19, there is also urgency for economic recovery. It has also resulted in the Tax Service Office increasing the issuance of Requests for Explanation on Data and/or Information (SP2DK) and Inspection Warrant (SP2) for the Payer. Taxes, in order to test taxpayer compliance following Article 4 of the Minister of Finance Regulation No. 184 / PMK.03 / 2015.

Considering that tax is a significant and definite source of state revenue, testing taxpayer compliance is a must and per statutory provisions, especially during the Covid-19 pandemic.

Tax is a mandatory contribution or contribution to the State that is owned by a person or entity (Taxpayer) without receiving direct compensation, and is used for the State's needs for the most extraordinary prosperity people (According to Law Number 28 the Year 2007 Article 1 concerning General Provisions and Tax Procedures)

However, if it is reviewed from corporate/corporate taxpayers' interests, the main objectives of doing business are to get the maximum possible profit and pay the minimum tax. Moreover, in the conditions of the Covid-19 pandemic, corporate/corporate taxpayers also certainly hope that the continuity of their business (Going Concern) can be guaranteed.

According to R. Santoso Brotodihardjo in his book (1982, page 11) “Introduction to Tax Law" about the resistance to taxes, it explains that there are 2 (two) types of tax resistance to the Taxpayer. First Passive Resistance, which consists of obstacles that make tax collection difficult, is closely related to the economic structure, intellectual and moral development of the population and the tax collection system itself. Second, Active Resistance, which includes all efforts and actions directly aimed at the tax authorities and aims to avoid taxes. This active resistance can include Tax Planning, Tax Avoidance, Tax Evasion.

Tax Avoidance is an illegal resistance; deliberate tax avoidance is a violation of legislation and has the potential for criminal sanctions, considering that Taxes have been regulated in Indonesia Law. Tax Planning is illegal resistance and meets statutory requirements by maximizing taxpayer goals, namely tax saving. While Tax Evasion is a grey area in the Law Policy, some say that this resistance is illegal because it is not following the original purpose of making the Law.

To ensure the Company's business (Going Concern), a wise Tax Payer should carry out Tax Planning per statutory policies. Due to the wide range of information exchange sources obtained from the Directorate General of Taxes, resistance such as Tax Avoidance and Tax Evasion is a resistance that is not following the principles of Going Concern Company and can have fatal risks.

For this reason, Tax Planning, which is under the laws and regulations in Indonesia, must be something that Tax Payer need to study more deeply, especially companies that run their business in Indonesia. This article will discuss what the companies in Indonesia pay attention to in realizing tax planning that is in line with the Company's vision and mission.

\section{THEORETICAL BASE}

\section{TAX}

Tax According to Law Number 16 of 2009 concerning General Provisions and Tax Procedures is a "compulsory contribution to the state owed by an individual or entity that is compelling under the Law, without direct reciprocity and is used for state needs for the amount of the great prosperity of the people."

"Taxes are all types of taxes collected by the Central Government including Customs and Excise, and taxes collected by the Regional Government, based on the prevailing laws and regulations" (Article 1 point 2 of Law No.14 of 2002 Tax courts).

"Taxes area all types of taxes collected by the Central Government, including Customs and Excise, and taxes levied by the Regional Government according to local laws and regulations" (Article 1 number 1 of Law No.19 od 2000 concerning Tax Collection by Force Letters).

"Regional tax, hereinafter referred to as a tax, is an obligatory contribution to the region owed by an individual or entity that is compelling based on law, without receiving direct compensation and is used for regional needs for the greatest prosperity the people". (Article 1 point 10 Law No.28 of 2009 concerning Regional Taxes and Regional Retributions).

\section{TAX PLANNING}

According to Chairil Anwar Pohan in his book Comprehensive Discussion of Indonesian Taxation (2014:13), Tax Planning is "A business that includes tax planning so that the tax paid by the company is truly efficient". 
In line with the above understanding, according to Arles P. Ompusunggu in the book How Legal Strategy Tax (2011:5), Tax Planning is "A capacity owned by taxpayers (WP) to reduce financial activity in order to obtain minimal tax expenses".

According to Erly Suandy (2003:7), "Tax planning is the initial stage in tax savings. The tax savings strategy is prepared at the time of planning, and tax planning is a legal effort that taxpayers can make.

From the above definitions, it can be interpreted that tax planning is an effort made by taxpayers to minimize the tax burden that must be paid. According to Sophar (1999) in Chairil Anwar Pohan's Book on Comprehensive Discussion of Indonesia Taxation (2014:24), there are six ways to minimize the tax burden that is usually practised, such as :

\section{Tax Shifting \\ 2. Capitalization \\ 3. Transformation \\ 4. Tax Evasion \\ 5. Tax avoidance \\ 6. Tax Exemption}

\section{INCOME}

According to Article 4 paragraph 1 of Law No.36 the Year 2008 concerning Income Tax, Income is defined as IncomeIncome, which is an additional economic capability received or obtained by Taxpayer, whether origination from Indonesia or from outside Indonesia, which can be used for consumption or to increase the wealth of the Taxpayer. The tax concerned, in whatever name and form.

In Indonesian Law, Income is divided into three categories, such as :

1. Income following Article 4 paragraph 1 of Law No.36 the Year 2008 concerning Income Tax, Including :

a. Compensation or remuneration in respect of work or services received or obtained including salaries, wages, allowances, honoraria, commissions, bonuses, gratuities, pension payments, or other forms of compensation unless otherwise stipulated in this Law;

b. Prizes from raffles or job or activities, and awards;

c. Operating Profit;

d. Profits due to sale or transfer of assets include :

1. Gains due to transfer of assets to companies, partnerships, and other entities in the list of shares or equity participation;

2. Gains from the transfer of assets to shareholders, partners, or members obtained by the Company, partnership, and other entities;

3. Profits due to liquidation, merger, consolidation, expansion, splitting, acquisition of a business, or reorganization under whatever name and form;

4. Profits due to the transfer of assets in the form of grants, assistance, or donations, except for those given to blood relatives in a straight line of one degree and religious departments, educational department, social agencies including foundations, cooperatives, or individuals running micro and small business, whose provisions are further regulated by a Regulations of the Minister of Finance, as long as there is no relationship with the business, occupation, ownership or control of the parties concerned; and

5. Profits due sale or transfer of part of all of the mining rights, participation in financing, or capital in mining company;

e. Receipt of return of tax payments that have been charged as cost and an additional payment of tax refunds;

f. Interest including premium, discount, and compensation for debt payment guarantees;

g. Dividends, in whatever name and form, including dividends from insurance companies to policyholders, and distribution of IncomeIncome from the cooperative;

h. Royalty or compensation for the use of rights;

i. Rent and other IncomeIncome in connection with use of assets;

j. Receipt or collection of periodic payments;

k. Gains due to debt relief, except up to a certain amount as stipulated by a Government Regulation;

1. Foreign exchange gains;

m. Excess difference due to asset revaluation;

n. Insurance premium;

o. Contributions received or obtained by association from its members, which consist of taxpayers who run independent businesses or jobs;

p. Additional net assets originating from IncomeIncome that has not been taxed;

q. Income from sharia-based businesses; 
r. Interest compensation as referred to in the Law concerning general tax provisions and procedures; and

s. Bank Indonesia surplus.

2. Final IncomeIncome with accordance with Article 4 paragraph 2 of Law No.36 the Year 2008 concerning Income Tax, such as :

a. Income in the form of interest on deposits and other savings, interest on bonds and government debt securities, and interest on deposits paid by the cooperative members;

b. Income in the form of lottery prizes;

c. Income from transactions in shares and other securities, the derivative transaction for the sale of shares or transfer of equity participation in a partner company received by a venture capital company;

d. Income from transfer of property transactions in the form of land and/or buildings, construction service business, real estate business, land and/or building leasing; and

e. Other certain Income, which is regulated by or based a government regulation.

3. Non-Taxable Income following Article 4 paragraph 3 of Law Np. 36 the Year 2008 concerning Income Tax, including :

a. 1. Assistance or donations, including zakat received by amil zakat group or amil zakat institutions established or authorized by the Government and received by entitled zakat recipients or mandatory religious donations for adherents of recognized religions in Indonesia, which are accepter by the institution. Religions that are established or legalized by the Government and received by the recipient of the rightful contribution, the provisions of which are regulated by or based on Government Regulations; and

2. Grants received by blood relatives in a straight line of one degree, religious groups, educational; groups, social groups including foundations, cooperatives, or individuals running micro and small businesses, the provisions of which are regulated by or based on a Regulation of the Minister of Finance, as long as there is no relationship with the business, occupation, ownership or control of the parties concerned;

b. Legacy;

c. Assets including cash deposits received by the entity as referred to in Article 2 paragraph (1) letter b as a substitute for shares or as a substitute for capital participation;

d. Replacement or compensation in connection with work or services received or obtained in-kind and/or enjoyment from the Taxpayer or the Government, except for those provided by non-taxpayers, taxpayers who are subject to final tax or taxpayers who use special calculation norms (deemed profit) as referred to in Article 15;

e. Payments from insurance companies to individuals in connection with health insurance, accident insurance, life insurance, endowment insurance, and scholarship insurance;

f. Dividends or part of profits received or received by limited liability company as a resident taxpayer, cooperative,state-owned Company, or regional-owned business entity, from capital participation in a business entity that is established and domiciled in Indonesia with the following conditions:

1. Dividends come from retained earnings reserves; and

2. For limited liability company, state-owned enterprised and regional-owned enterprises that receive dividends, share ownership in entities that pay dividends is no less than $25 \%$ (twenty-five per cent) of the total paid-up capital;

g. Contributions received or obtained by the pension fund whose establishment has been approved by the Minister of Finance, whether paid by the employer or by the employee;

h. Income from capital invested by pension funds as referred to in $\mathrm{g}$, in specific fields which are stipulated by a Decree of the Minister of Finance;

i. Share of profits received or received by members from a limited partnership whose capital does not consist of shares, partnerships, associations, firms, and together, including the uni holders of collective investment contracts;

j. Deleted;

k. Income received or earned by a venture capital company in the form of a share of profits from a business partner entity that is established and runs a business or activity in Indonesia, provided that the partner entity:

1. Is a micro, small, medium-sized company or one that carries out activities in business sectors regulated by or based in a Regulation of the Minister of Finance; and

2. Its shares are not traded on a stock exchange in Indonesia;

1. Scholarships that meet specific requirements whose provisions are further regulated by or based on a Regulation of the Minister of Finance;

m. The excess received or obtained by the non-profit agency/institution engaged in education and/or research and development have been registered on the agency in charge of it. Also reinvested in the form of facilities and infrastructure for education and research and development activities, within a maximum period of 4 (four) years since an excess of the excess is obtained, the provisions are further stipulated by or based on Regulations of the Minister of Finance 
n. Furthermore, the Social Security Administering Group's Assitance or compensation to certain taxpayers, the provisions of which are further regulated by or based on a Regulation of the Minister of Finance.

\section{COSTS}

\subsection{Deductible Expenses}

According to Article 6, paragraph 1 of Law No.36 of 2008 concerning income tax, the amount of taxable IncomeIncome for domestic taxpayers and permanent establishments is determined based on gross IncomeIncome fewer costs to obtain, collect and maintain IncomeIncome, including:

a. Costs that are directly or indirectly related to business activities

b. Depreciation of expenditures to acquired tangible assets and amortization of expenses for obtaining rights and other costs which have a useful life of more than 1 (one) year as referred to in Article 11 and Article 11A;

c. Contributions to pension funds whose establishment has been approved by the Minister of Finance;

d. Losee due to sale or transfer of property owned and used in the Company or owned to obtain collect and maintain IncomeIncome;

e. Loss on foreign exchange rates;

f. The cost of research and development for companies carried out in Indonesia;

g. Scholarship, internship, and training costs;

h. Uncollectible receivables;

i. Donations in the context of national disaster management, the provisions of which are regulated by a Government Regulation;

j. Donations in the framework of research and development carried out in Indonesia, the provisions of which are regulated by a Government Regulation;

k. Government Regulations regulate social infrastructure development costs, the provisions of which;

1. Donation of educational facilities, the provisions of which are regulated by a Government Regulation; and

m. Donations in the framework of sports fostering, the provisions of which are regulated by a Government Regulation.

\subsection{Non-Deductible Expenses}

According to Article 9 of Law No.36 the Year 2008 regarding Income Tax:

1. To determine the amount of Taxable Income for a resident Taxpayer and a permanent establishment, it may not be deducted:

a. Distribution of profit in whatever name and form, such as dividends, including dividends paid by insurance companies to policyholders, and distribution of the remainder of the cooperative's operating IncomeIncome;

b. The cost charged or incurred for the personal benefit of shareholders, partner or members;

c. The establishment or accumulation of reserve funds, except:

1. Reserves for an uncollectible account for banks and other business entities that extend credit, leasing with option rights, consumer finance companies, and factoring companies;

2. Reserves for insurance businesses, including social assistance reserves established by the Social Security Administering Group;

3. The guarantee reserve for the Deposit Insurance Corporation;

4. Reserves for reclamation costs for forestry businesses;

5. Reserves for replanting costs for forestry businesses; and

6. Reserves for the cost of closing and maintaining industrial waste disposal sites for industrial waste treatment business, whose terms and conditions are regulated by or based on a Regulation of the Minister of Finance;

d. Health insurance premiums, accident insurance, life insurance, endowment insurance, and student scholarship insurance, which is paid by an individual taxpayer, unless paid by the employer and the premium is calculated as Income for Taxpayer concerned;

e. Compensation of work or services provided in the form of in-kind and enjoyment, except for the provision of food and drink all employees as well as replacement or remuneration in the form of in-kind and enjoyment in certain areas and connection with the implementation of work regulated by or based on a Regulation of the Minister of Finance;

f. An amount that exceeds the fairness paid to shareholders or related parties as compensation for the work performed;

g. Donated assets, assistance or donations, and inheritance as referred to in Article 4 paragraph (3) letter a and letter b, except donations as intended in Article 6 paragraph (1) letter i to letter $m$ and zakat received by the amil zakat group or amil zakat institutions established or legalized by the Government or compulsory religious donations for adherents of recognized religions in Indonesia, received by religious institutions established or legalized by the Government, the provisions of which are regulated by or based on Government Regulations;

h. Income Tax;

i. The cost that is charged or incurred for the personal benefit of the Taxpayer or his dependent person;

j. Salaries paid to members of an association, firm, or limited partnership whose capital does not consist of shares;

k. administrative sanctions in the form of interest, fines and increases, and criminal sanctions in the form of fines relating to the implementation of laws in the field of taxation. 
2. Expenditures to obtain, collect, and maintain IncomeIncome that has a useful life of more than 1 (one) year are not allowed to be charged at once but are charged through depreciation or amortization as referred to in Article 11 or Article 11A.

\section{INCOME TAX RATE}

Article 5 of Law Number 2 of 2020 concerning Stipulation of Government Regulations explains, "Adjustment of income tax rates for the domestic taxpayer and permanent establishments (25\%), reduct to : 22\% covering the Tax Year 2020 and Fiscal year 2021 and $20 \%$ which will come into effect in the 2022 Fiscal Year".

\section{RESEARCH METHODOLOGY}

In this study, researchers used qualitative research methods with a case study approach, such as research conducted with literature review according to the main research question regarding how the influence of Tax Planning on contemporary or current phenomena in the context of Tax Saving (Robert, 2002:1).

A case study is an empirical inquiry that investigates phenomena in the context of real-life when the boundaries between the phenomena in the context are not visible and where multiple sources of evidence are used (Robert, 2002:18)

In the book Moleong (2014: 4), Bogdan and Taylor say that qualitative research methods are research procedures that produce descriptive data in the form of words or words from people and observable behaviour. This approach is directed at the setting and the individual holistically or intact. In this study, it is not allowed to isolate individuals or organizations into variables or hypotheses. However, it is necessary to see them as part of a whole.

\section{RESEARCH RESULTS AND DISCUSSION}

According to Law No.03 of 1982 concerning Company Registration Obligations, a company is any form of business that is permanent, continuous and which is established, work and is domiciled in the territory of the Republic of Indonesia. The Company's goal is to make a profit (profit).

Furthermore, Law No.8 of 1997 concerning Company Documents Article 1 point 1 explains that a company is any form of business that carries out activities regularly and continuously by obtaining profits and/or profits, whether organized by individuals or business entities in the form of an entity. The legal or non-legal entity, which is established and domiciled in the Republic of Indonesia's territory.

Then Law Number 16 of 2009 concerning General Provisions and Tax Procedures explains that taxes are "compulsory contributins to the State that are owed by private persons or entities that are compelling under the Law, without direct reciprocity and used for state purposes. For the greatest prosperity of the people."

Considering that the purpose of establishing a company (business entity) is to make a profit, there is resistance to tax obligations. This resistance is shared by Brotodihardjo in his book Introduction to Tax Law (1982:11) into passive resistance and active resistance.

This passive resistance takes the form of obstacles that complicate tax collection and has a close relationship with the economic structure with the population's intellectual and moral development and tax collection techniques itself (Brotodihardjo, 1982, page. 11). Passive resistance will also arise if the control system is not carried out effectively or cannot even be carried out. In some countries, this passive resistance to indirect taxes is less intense than direct taxes. Therefore, in general, most countries tend to apply indirect taxes.

Brotodihardjo (1982, page. 12) explains that active resistance includes all efforts or actions directly aimed at tax authorities and aim to avoid taxes. The form can be :

1. Avoidance of taxes, namely taxes, can be easily avoided by not taxable actions or Tax Avoidance.

2. Tax evasion/smuggling, such as tax evasion by way of evasion, breaking the Law (illegal) or Tax Evasion.

3. Avoid taxes, such as refusing to pay a tax that has been determined and refusing to comply with formal requirements that must be met, for example, by blocking the confiscation process.

However, the Tax Resistance raised by Brotodihardjo above is not the best solution for business entities. Especially in Indonesia, where the obligation to pay taxes has been regulated in the Law Policy. For this reason, business entities wishing to Going Concern should obey to pay taxes by carrying out Tax Management (Tax Planning). So that profit goals can be directed and realized.

According to Griffin the definition of management is as follows: “...Management ... can be defined as a set of activities (including planning and decision making, organizing, leading, and controlling) directed at an organization's resources (human, financial, physical, and information), with the aim of achieving organizational goals in an efficient and effective manner" (Griffin, 2013, page. 5).

According Griffin, management is a process of planning (planning), organizing (organizing), directing (leading), and controlling (controlling) the resources of the organization to achieve goals effectively and efficiently. The organizational include human resources (human resources), financial (financial resources), physic (physical resources), and information (information resources).

Effective means that goals can be achieved according to planning. Efficient means that existing tasks are carried out correctly, organized, and according to schedule. In tax management, the four processes above are a series of interrelated 
ISSN 2250-3153

processes. The above process can be carried out in an unorderly manner so that effectiveness and efficiency can be created properly.

Prianto Budi, in his book Tax Management (2016, Page 160), explains that "The most important thing in the first stage of tax management is to set goals, formulate strategies, and develop plans. So the implementation of these strategies can be coordinated so that the objectives set are achieved effectively and efficient". Tax planning cannot be separated from company business planning. Tax planning must be an integral part of company business planning, And tax planning is an inseparable part of the business.

In Tax planning, several conditions must be met. The first is to understand the provisions of taxation. A good understanding of taxation regulations can be used to save taxes. As Sun Tzu, "If you know your enemy and know yourself, you need not be afraid of the result of hundred of battles. " In order to save taxes according to the Law, we must study tax policy.

TO understand a tax rule and look for regulatory loopholes that can benefit Tax Payers, taxpayers, or tax consultants who read the regulations must equip themselves with tools, such as the science of Law with legal interpretation sub-language.

Freeman (In "The Art of the Loophole: Making the law work for you" in 2012), explain "The art of the loophole is finding a way to stop the prosecution from being able to do that". Freeman tried to stop the prosecution of his client. His approach was to obtain the first prosecution files before obtaining detailed instructions and study them like using a microscope (Pickup, 2012). In this regard, Freeman stated as follows:“...To defend a case with a loophole argument, a lawyer has to look forensicallythrough the court papers before forming an opinion and arming his a client with all information they need so that they can decide how to plead....".

In his book, Freeman also describes several principles in applying the art of looking for loopholes in the tax court's legal context. Including keeping a look at the Taxpayer situation from every point of view until a solution is found (keep looking at your situation from every single angle until you find a solution). Moreover, get a better understanding of tax rules from other parties and interpret the main rules (know the rules far better than your opponent and read around the subject) (Pickup, 2012).

In short, the main element (loophole hunting) is knowledge (knowledge). To understand technical provisions that can reveal weaknesses in tax law cases, taxpayers must explore, read, and conduct research to taxpayers to find loopholes that can benefit taxpayers.

As an example of the issuance of PP 46/2013, many MSME businesses use this Regulation to save taxes, including professional service businesses such as Tax Consultant Service. Because PP 46/2013 raises a grey area, then PP 23/2018 was issued, limiting MSME players who can take advantage of this $0.5 \%$ Tariff.

According to Diane Kennedy in a book on Loopholes of the Rich (2005, page. xi-xii), as quoted below, tax loopholes are government incentives to encourage public Policy. Tax loopholes are not fraudulent or sneaky. The Government wants it obligatory. Taxes to take advantage of tax loopholes legally correspond to loopholes provided in tax regulations. Tax gaps are most prevalent in the two areas that most sustain the economy, such as business and real estate investment.

"Loopholes are government incentives to promote public Policy. They aren't something shady or shifty. In fact, the Government wants you to take advantage of the legal tax loopholes that the tax law provides. So where are the loopholes? You'll find most of the loopholes in the two areas that most support the economy-businesses and real estate investing Businesses, and particularly small businesses, provide stimulus to the economy. A growing business employs people, hires consultants, invests in equipment, and just generally kick-starts a struggling economy. In fact, look at recent tax legislation. Does it seem like the tax cuts are unfair? They are! That's because the Government wants to create a change in the economy and knows that the best way to do that is by creating opportunities for businesses to grow." (Kennedy, 2005, page. xi-xii).

In order to save taxes, what we need to know is how to pay taxes correctly. As a quote from Kennedy, Government wants to create economic change, and the best way to do this is by creating opportunities for business to thrive. In addition to encouraging MSME players to do bookkeeping, PP 23/2018 also aims to create economic change in Indonesia.

Second, Understanding the purpose of Tax planning is efficient and effective in fulfilling tax obligations. Saving taxes is the primary goal of tax planning, so that it must be carried out correctly, organized, and on schedule.

Following Perppu 1 of 2020, the Indonesian Government has reduced the corporate income tax rate from 25 per cent to 22 per cent for the 2020 and 2021 tax years and 20 per cent starting from the 2022 tax year. With the enactment of this Regulation, several corporate taxpayers are also competing for the competition utilizes financing in $2020-2021$ by increasing costs in the year concerned. Maximizing the cost in question increases the deductible costs, including using the depreciation and amortization method with the declining balance method, by companies using the tax rates of article 17 and article 31e. The use of depreciation in vehicles as tax savings has also increased since the issuance of the Decree of the Minister of Industry of the Republic of Indonesia No. 169/2021 concerning motorized vehicles with Sales Tax on luxury goods that the Government bears in the fiscal year 2021

Third, Understanding and identifying transactions and assessments with tax consequences in transactions, each division's corporate Taxpayer must remind each other of the tax consequences. Each of these divisions should be equipped with knowledge in identifying the tax consequences of the transaction's transaction. For example, when a taxpayer buys inventory goods, the purchasing must identify there is an obligation to pay VAT and request a tax invoice with the vendor. If the corporate Taxpayer pays for shipping services, the corporate Taxpayer must deduct income tax on shipping services. Moreover, Accounting must ask for archival evidence withholding income tax 23.

Some of the risks that taxpayers will face, first when they do not carry out their obligation to collect and withhold PPh Article 23 , taxpayers are required to pay a fine of $2 \%$ of the tax principal payable per month and a maximum of $48 \%$. Second, due to new errors found during the implementation of tax audits by the Directorate General of Taxes on Past Tax Returns, the Payable Tax Principal / a Tax Credit for the service provider develops a disability (expired) service provider has completed the Corporate Tax Return. Corporate taxpayers cannot collect the tax principal owed to the service provider, and the corporate Taxpayer has to pay 
ISSN 2250-3153

the tax from themselves. Third, The tax does not cover the corporate Taxpayer's Taxable Profit, fourth, because the tax penalty is not an allowable income deduction, meaning that the corporate Taxpayer's tax will be $25 \%$ greater than the total tax penalty incurred. Finally, there is an additional workload and time for the tax section of corporate taxpayers, because they have to find a way out and seek arguments to annual the tax auditor's findings.

Fourth, Documentation and bookkeeping that meet the requirements. Documents are evidence of transactions and the basis for determining taxes. Even in an audit, the tax auditor will always ask for a financial report or ledger. Information from the financial statements and ledgers recorded is the basis for tax auditors to test taxpayer compliance. It is better if corporate taxpayers present their books correctly and adequately.

Sometimes there are differences between accounting and tax that require recalculation or fiscal correction. However, Article 28 paragraph 7 of Law Number 16 of 2009 concerning General Provisions and Tax Procedures states that Taxpayer based on Financial Accounting Standards.

In a company engaged in the construction sector, If it uses Accrual basic recording, then compiling the Annual SPT will need to make fiscal corrections. As regulated in Article 4 paragraph, 2 of Law No.36 of 2008 concerning Income tax, income tax on construction companies is a final tax. So that the income tax at the construction company is payable as it has been received. Sometimes because of carrying out the accrual basic, taxpayers have to make fiscal corrections due to differences in IncomeIncome recognized in the commercial report with the fiscal report. Tax auditors often interpret that Income, if it has been recognized, will be tax payable and must be paid no later than the 10th after the month due.

Considering that different types of business fields may be subject to different treatment for their tax obligations, it is better if corporate taxpayers in Indonesia understand government policies to save taxes efficiently and effectively.

1. Government Regulation of the Republic of Indonesia Number 46 of 2013, and Number 23 of 2018 concerning Income Tax on Income from Businesses that are received or obtained by Taxpayers who have an inevitable gross turnover (PP 46/2013 and PP 23/2018)

Based on making it easier for MSME taxpayers in tax administration, the Government issued a PP 46/2013 policy. With PP 43/2013, taxpayers who have a gross circulation of below 4.8 billion are categorized into the MSME group. For MSME taxpayers, the tax payable is no longer subject to the tax rate of article 17 (25\%) of net IncomeIncome, but only $0,5 \%$ of the gross calculation. The PP 46/2013 policy is sufficient to help MSMEs that are just start-up, from administration, simplify bookkeeping, calculate company profits. For start-up companies, they can reduce the cost of paying accounting or consultants in terms of fulfilling their Company's tax obligations.

The PP 46/2013 policy is sufficient to help MSMEs that are just start-up, from administration simplify bookkeeping, calculate company profits, etc. They can save the cost of paying accounting or consultants for start-up companies in terms of fulfilling their Company's tax obligations.

With particular consideration in PP 46/2013, specific services related to free employment are then also limited and not permitted to use tax rates according to PP23 of 2018.

Services related to independent work that cannot take advantage of PP 23/2018 include (a) experts who do independent work, consisting of lawyers, accountants, architects, doctors, consultants, notaries, PPAT, appraisers, and actuaries; (b) Musicians, presenters, singers, comedians, film stars, soap operas, commercials, directors, film crews, photo models, models/models, drama actors, and dancers; (c) athletes; (d) advisors, instructors, trainers, lecturers, extension agents and moderators; (e) authors, researchers and translators; (f) advertising agency; (g) project supervisor or manager; (h) intermediaries; (i) officers selling merchandise; (j) insurance agents; (k) distributors of multi-level marketing or direct selling companies and other similar activities.

According to the beneficiaries, PP 23/2018 still provides Loopholes, especially tax consultant work services. It happens because the limitation on consulting service experts in Government Regulation No. 23 of 2018 only limits experts who are not allowed to take advantage of this tariff, which is in the form of an individual and a CV, where the expert has provided his services directly as a legal person in physics. However, it does not prohibit this rate from being used by experts in the form of Limited Companies. Tax Consultants also use this Regulation to save their income tax by establishing a limited company.

The utilization period of this tariff is also limited by the issuance of PP 23 of 2018. The maximum benefit period is 3 (three) Tax Years for corporate Taxpayers in the form of limited liability companies, 4 (four) Tax Years for corporate Taxpayers in cooperatives, limited partnership, or firms. And 7 (seven) Tax Years for individual Taxpayers.

From the art of PP 23/2018 loopholes, If corporate taxpayers want to take advantage of the $0,5 \%$ rate for business, one way to break the Company's turnover of 4.8 billion into several companies not to reach 4.8 billion. Besides being able to free themselves from PKP, Entrepreneurs are required to levy taxes to still have competitiveness in the business. The final corporate tax and are not obliged to bookkeeping.

If a new company is established, it can save money with this Government Regulation according to a predetermined life. However, if the Company is fast to reach a large scale business, solving this turnover is not an option. Given the main problem in solving turnover is inventory stock, the flow of goods must also be considered. Controlling inventory goods' flow must be more thorough not to become an increase in income tax for the Company.

\section{Article 6 Paragraph 1 letter a section 2,6,7 in Law Number 36 the Year 2008 concerning Income Tax.}

According to Article 6 Paragraph 1 of Law Number 36 the Year 2008 concerning Income Tax, "The amount of taxable income for domestic taxpayers and permanent establishments is determined based on gross income less costs to obtain, collect, and maintain income". The fees in article 6, paragraph 1 regarding income tax are often reoffered to as deductible costs. In tax planning, deductible costs must be the maximum so that corporate taxpayers can save on the income tax they pay. 
One of the Deductible fees following Article 6 Paragraph 1 of the Income Tax Law described in letter a part 2 is "costs related to work or services including wages, salaries, honoraria, bonuses, gratuities, and allowances provided in the form of money". Tax Planning by maximizing this deductible cost can be done to increase the benefits in employee salaries.

For example, providing lunch to every employee in the office should be recorded as a meal allowance in the employee's salary. It does not become a gift in kind to the employee, which is a non-deductible expense. Suppose the Company provides income tax allowances 21 to employees. In that case, it should also be used as income tax allowances 21 because making the allowances a deductible cost can reduce taxable Income (PKP) in calculating the tax payable.

Providing pph 21 allowances to employees, especially employees whose taxable IncomeIncome does not reach Rp 50.000 .000 ,- is more economical than the $25 \%$ corporate income tax rate (up to 2021). Because the rate is around 5-6\% after-tax deduction (6\% if you do not have an NPWP) However if the corporate income tax rate is imposed, the tax is between $12,5 \%$ $25 \%$ (depending on whether the Company gets a 50\% deduction facility from the rate of article 17).

Likewise, in article 6, paragraph 1, letter a, section 6 of the Income Tax Law on travel expenses. In small and medium-sized companies, the directors who frequently travel on business are directors. Moreover, payment of official travel expenses by the directors can be challenged by the tax inspector. Travel tickets can be deductible, but it is different from consumption costs for directors. For this consumption cost to become deductible expenses, it needs to be used as a meal allowance in the directors ' salary.

Also, in article 6 paragraph 1 letter, section 7 of the Income Tax Law concerning promotion and sales costs as stipulated in the Regulation of the Minister of Finance Number 02/ PMK.03/2010. Part of the Taxpayer's sales costs in the context of introducing and/or recommending the use of a product, either directly / indirectly to maintain and/or increase sales, is a deductible cost. With this, corporate taxpayers can make tax savings by investing in advertising, product samples, sponsorship and product exhibitions into the Taxpayer's financial statements, including Value Added Tax. For example, a sample of a product that is an object of VAT, corporate taxpayers can pay for it in promotion and sales costs in its recording on the said VAT.

\section{Article 5 of Law Number 2 of 2020 concerning stipulation of Government Regulations, Article 6 paragraph 1 letter b and Article 9 paragraph 2 of the Income Tax Law.}

As stated in Article 6 paragraph 1 letter b of the Income-tax Law, "depreciation of expenditures to acquire tangible assets and amortization of expenses for obtaining rights and other costs which have a useful life of more than 1 (one) year". Companies that are already profitable buy production tools and machines and require more supportive cash flow to expand their business. So that at this time, if they want to reduce the payment instalments of prepaid tax art 25 in the following year, then the solution can be to use the depreciation method system for production tools and machines with a declining balance method.

Maximizing this cost is also the best option for corporate taxpayers who buy tangible assets and intangible assets in the year before 2022. According to Article 5 of Law Number 2 of 2020 concerning the Establishment of Government Regulations, it explains an income tax rate adjustment of $22 \%$. The 2020 tax year and 2021 tax year will be $20 \%$ starting from the 2022 tax year. Therefore, if the depreciation or amortization is carried out in the year before 2022, it can also save taxes payable to be paid and reduce the potential for the instalment of prepaid tax art 25 tax deposits overpayment.

Expenses financing in the future is considered not to be of great benefit to the Company. Nevertheless, if costs are depreciated early, it will generate future value for the company finances. It is in line with financial accounting, which expects taxpayers to include Deferred Tax Asset and Deferred Tax Liabilities on the Company's balance sheet.

The same thing happens in article 6 paragraph 1 letter $d$ of the Producing Tax Law, such as "losses due to the sale or transfer of property owned and used in a company or owned to obtain, collect, and maintain income". If paid for in the tax year with a higher tax rate, it will be more efficient. Furthermore, if there is a profit on the sale or transfer of property, it is better if the sale is shifted in the tax year with a lower tax rate.

In addition to increased depreciation and amortization costs, costs can be increased concerning National Disaster Management Contribution, Research and Development Contribution, Educational Facility Contribution, Sports Development Contribution Social Infrastructure Development Costs deducted from Gross Income (Government Regulation Number 93 of 2010).

However, the donations above must meet several conditions, including the Taxpayer having net tax income based on the previous Annual Income Tax Return, donations and/or expenses do not cause a loss in the tax year the donation is given valid evidence. The receiving institution donations and/or fees have a NPWP, except for exempted entities as tax subjects.

Apart from giving donations, the practice of exploiting costs is often found in companies by capitalizing costs. Article 9 paragraph 2 of the Income Tax Law states that expenses for obtaining, collecting and maintaining IncomeIncome with a useful life of more than one year may not be charged at once but through depreciation (article 11) or amortization (article 11A).

In its applicatiion, costs that can be capitalized include, among the others, cost incurred in order to acquuire assets, such as import duites transportation costs \& installation costs (according to the elucidation of Article 10 paragraph 1); Input VAT taht cannot be credited and can be charged, if it is related to the acquisition of tangible assets and / or intangible assets, must be capitalized and charged through depreciation and amortization (in accordance with Article 10 of Goverment Regulation No. 94/2010); BPHTB on land owned / used to obtain, collect, and maintain IncomeIncome, can be deducted as an expense through amortization of land rights as long as it can be amortized in accordance with Article 11A, BPHTB for buildings owned / used obtain, collect, and maintain IncomeIncome, can be deducted as expenses through depreciation (as per SE 01/PJ.42/2002); Interest \& Construction Overhead Costs incurred during construction must be capitalized into the cost of the building and charged by depreciation (SE22/PJ.42/1999); Land rights must first be capitalized into the cost of land ( as explained in article 11). 
If capitalization is carried out, it will increase the deduction of taxable IncomeIncome and provide more excellent future value to the Company if this capitalization occurs in an income tax year with a higher tax rate than the following year the example mentioned above.

\section{CONCLUSIONS AND SUGGESTIONS}

The most crucial thing in company business planning is to achieve maximum profit. After the goals are sure, then the next stage in corporate tax management is in formulating strategies and developing plans so that the implementation of these strategies can be coordinated so that the objectives set are achieved effectively and efficiently.

In Corporate Tax planning, understanding taxation provisions is the key to success. A good understanding of travelling regulations can be used to save taxes. By understanding tax rules and equipping themselves with knowledge, it will be easier for taxpayers to find loophole hunting that can be profitable. Because getting a better understanding of tax rules from other parties and interpreting these rules' main rules is the Art of Loopholes.

They are considering that the main element in loophole hunting is knowledge. To understand technical provisions that can reveal tax law cases' weakness, taxpayers must continue to update, read, and conduct research in taxation policies until they are obliged. Taxes get loopholes that can benefit taxpayers.

Here are some ways to save taxes that can be done by corporate taxpayers in Indonesia are :

1. Maximize PP 23 of 2018 Policy for UMKM until 2020 (for corporate taxpayers in the form of Limited Liability Companies), 2021 (for corporate taxpayers in the form of cooperatives, limited partnership, or firms), 2024 (individual Taxpayers), reducing the turnover of business entities by formed several Limited Companies.

2. Changing the provision of in-kind in any form into allowances calculated in the employee's salary/ Allowances in the form of money are deductible expenses that meet the provisions of Article 6 of Law Number 36 the Year 2008 concerning Income Tax.

3. Providing 21 Income Tax Allowances for employees whose taxable IncomeIncome does not exceed Rp 50.000.000 will be able to reduce the income tax payable (to 5-6\%).

4. Shifting costs in the tax year with a higher rate can increase future value by maximizing the present costs.

\section{BIBLIOGRAPHY}

Bogdan, Taylor, dkk. 1992. Pengantar Metode Penelitian Kualitatif, Terjemahan oleh Arief Rurchan. Usaha Nasional: Surabaya. Robert, Mathis. 2002. Manajemen Sumber Daya Manusia. Salemba empat : Jakarta.

Undang-Undang Nomor 2 Tahun 2020 tentang Penerapan Peraturan Pemerintah Pengganti Undang-Undang Nomor 1 Tahun 2020 tentang Kebijakan Keuangan Negara dan Stabilitas Sistem Keuangan untuk Penangganan Pandemi Corona Virus Disease 2019 (Covid-19) dan/atau Dalam Rangka Menghadapi Ancaman yang membahayakan Perekonomian Nasional dan/atau Stabilitas Sistem Keuangan Menjadi Undang-Undang.

Peraturan Presiden Republik Indonesia Nomor 72 Tahun 2020 tentang Perubahan atas Peraturan Presiden Nomor 54 Tahun 2020 tentang Perubahan Postur dan Rincian Anggaran Pendapatan dan Belanja Negara Tahun Anggaran 2020.

Undang-Undang Republik Indonesia Nomor 36 Tahun 2008 tentang Perubahan Keempat Undang-Undang No 7 Tahun 1983 tentang Pajak Penghasilan. Direktorat Jenderal Pajak Kementerian Keuangan.

Kontan.co.id, Ternyata dari sini sumber penerimaan mayoritas negara di kawasan Asia Pasifik, 25 Juli 2019, terakhir diakses pada tanggal 04 April 2021, https://nasional.kontan.co.id/news/ternyata-dari-sini-sumber-penerimaan-mayoritas-negara-dikawasan-asia-pasifik.

Pajak.go.id, Laporan Kinerja Direktorat Jenderal Pajak 2019, terkahir diakses 04 April 2021, https://www.pajak.go.id/sites/default/files/2020-02/LAKIN\%20DJP\%202019.pdf.

Corona.Riau.go.id, Kumpulan Peraturan \& Pedoman Pengangan Covid-19, 01 April 20201, terakhir diakses pada tanggal 04 April 2021, https://corona.riau.go.id/wp-content/uploads/2020/04/Kumpulan-Peraturan-Pedoman-Penanganan-Covid-19.pdfcompressed compressed 2.pdf

Undang-Undang Republik Indonesia Nomor 16 Tahun 2009 tentang Perubahan Keempat atas Undang-Undang Nomor 6 Tahun 1983 tentang Ketentuan Umum dan Tata Cara Perpajakan. Direktorat Jenderal Pajak Kementerian Keuangan.

Brotodihardjo, Santoso. 1982. Pengantar Ilmu Hukum Pajak. Cetakan ke X. PT.Eresco: Jakarta-Bandung.

Merdeka.com, Tujuan Perusahaan Menurut Undang-Undang, Jenis dan Bentuknya, 22 Agustus 2020, terakhir diakses tanggal 06 April 2021, bentuknya.html?page=2.

Undang-Undang Republik Indonesia Nomor 3 Tahun 1982 tentang Wajib Daftar Perusahaan.

Undang-Undang Republik Indonesia Nomor 8 Tahun 1997 tentang Dokumen Perusahaan.

Budi S, Prianto. 2016.Manajemen Pajak.Teori dan Aplikasi Edisi 2. PT Pratama Indomitra Konsultan : Jakarta.

Kennedy, Diane. 2005. Loopholes of the Rich. John Wiley \& Son, Inc. : Canada.

Pickup, D. R. (2012, November 1). BOOK REVIEW: The Art of the Loophole: Making

the Law Work For You. Diambil kembali dari http://www.lawgazette.co.u:

http://www.lawgazette.co.uk/analysis/reviews/book-review-the-art-of-theloophole-making-the-law-work-foryou/68085.fullarticle. 
Peraturan Pemerintah Republik Indonesia Nomor 23 Tahun 2018 tentang Pajak Penghasilan atas Penghasilan dari Usaha yang diterima atau diperoleh Wajib Pajak yang memiliki peredaran bruto tertentu.

Peraturan Menteri Keuangan Republik Indonesia Nomor 02/PMK.03/2010 tentang Biaya Promosi yang dapat dikurangkan dari Penghasilan Bruto.

Undang-Undang Nomor 2 Tahun 2020 tentang Penetapan Peraturan Pemerintah Pengganti Undang-Undang Nomor 1 Tahun 2020 tentang Kebijakan Keuangan Negara dan Stabilitas Sistem Keuangan untuk Penanganan Pandemi Corona Virus Disease 2019 (COVID-19) dan/atau dalam Rangka Menghadapi Ancaman yang Membahayakan Perekonomian Nasional dan/atau Stabilitas Sistem Keuangan menjadi Undang-Undang.

Peraturan Pemerintah Republik Indonesia Nomor 93 Tahun 2010 tentang Sumbangan Penanggulangan Bencana Nasional, Sumbangan Penelitian dan Pengembangan, Sumbangan Fasilitas Pendidikan, Sumbangan Pembinaan Olahraga, dan Biaya Pembangunan Infrastruktur Sosial yang dapat dikurangkan dari Penghasilan Bruto.

Peraturan Pemerintah Republik Indonesia Nomor 94 Tahun 2010 tentang Perhitungan Penghasilan Kena Pajak dan Pelunasan Pajak Penghasilan dalam Tahun Berjalan.

Surat Edaran Direktur Jenderal Pajak Nomor 01/PJ.42/2002 tentang Perlakuan Pajak Penghasilan atas Pengeluaran untuk Bea Perolehan Hak atas Tanah dan Bangunan (BPHTB) dan Pajak Bumi dan Bangungan (PBB) sebagai biaya/pengurang Penghasilan Bruto.

Pohan, Chairil Anwar. 2014. Pembahasan Komprehensif Perpajakan Indonesia Teori dan Kasus. Mitra Wacana Media : Jakarta.

Ompusunggu, Arles P. 2011. Cara Legal Siasati Pajak. Puspa Swara: Jakarta.

Suandy, Erly. 2003. Perencanaan Pajak, Edisi Revisi. Salemba Empat: Jakarta. 